\title{
PROBLEM PERNIKAHAN DAN STRATEGI PENYELESAIANNYA: STUDI KASUS PADA PASANGAN SUAMI ISTRI DENGAN USIA PERKAWINAN DI BAWAH SEPULUH TAHUN
}

\author{
Satih Saidiyah, Very Julianto \\ Program Studi Psikologi Fakultas Ilmu Sosial dan Humaniora Universitas Islam Negeri (UIN) Sunan Kalijaga \\ Jalan Marsda Adisucipto Yogyakarta \\ satihsaidiyah@yahoo.com
}

\begin{abstract}
This study was aimed to explore marriage problems experiencing by couple who had been married for 5-10 years in Yogyakarta and to find out the strategies to solve their problems to be recommended for the counseling section of Ministry of Religious Affair, Indonesia. This study employed qualitative method, particulary case study method. The subjects were 4 couple who had been married for 5-10 years and lived in Yogyakarta. The data was collected using in-depth interview and observation techniques. The data were analyzed using open coding and axial coding. The result of this study showed two initial problems of 5 years marriage: financial prolems and adaptation between marriage couples and extended families. The two strategies to overcome those problems were: building a healthier communication a marriage in the first 5 years, married couples should get stability income and 2) to find the way out to adapt between marriage partners and the whole families. The problems of 6-10 years marriage were: the difference between couple in term of parenting style, the decreasing of positive behavior, and the change of communication between couple. The strategies to overcome them were: begin to use positive open communication, including to make agreement about parenting style used in family and repeat the previous positive habits, in which could make greater intimacy and commitments in marriage. The strategies could be used make a warmer and happier marriage.
\end{abstract}

Keywords: self-help; problems in marriage; strategies

\begin{abstract}
Abstrak
Penelitian ini bertujuan untuk mendalami masalah-masalah yang terjadi pada pernikahan usia 5-10 tahun di Yogyakarta dan membuat strategi penyelesaian yang dapat direkomendasikan kepada bagian Kepenghuluan Kementerian Agama RI. Metode yang digunakan dalam penelitian ini adalah studi kasus dengan subjek yang memiliki karakteristik telah menikah selama 5-10 tahun dan bertempat tinggal di Yogyakarta. Teknik pengambilan data dengan wawancara dan obervasi. Analisis data dilakukan dengan menggunakan open coding dan axial coding. Hasil penelitian ini menunjukkan bahwa ada dua masalah pada usia menikah 5 tahun yaitu masalah ekonomi dan adaptasi kebiasaan pasangan suami-istri dengan keluarga besar. Strategi yang di lakukan adalah mengenali komunikasi dan menjadikan keluarga sebagai penengah. Adapun pasangan dengan usia pernikahan 6-10 tahun cenderung menghadapi masalah perbedaan pengasuhan anak, perubahan sikap positif yang hilang setelah lama menikah dan komunikasi yang berubah antar pasangan. Strategi penyelesaian masalah dilakukan dengan membuka kembali komunikasi yang lebih efektif khususnya terkait perbedaan pengasuhan anak dan mengembalikan kebiasaan positif yang dapat menguatkan intimasi dan komitmen pernikahan. Strategi tersebut diterapkan untuk menjadikan pernikahan kembali hangat dan bahagia.
\end{abstract}

Kata kunci : self-help; masalah pernikahan; strategi

\section{PENDAHULUAN}

Pernikahan adalah suatu ikatan antara lakilaki dan perempuan yang telah menginjak usia dewasa ataupun dianggap telah dewasa dalam ikatan yang sakral (Marlina, 2013). Dianggap sakral karena dalam pernikahan hubungan antara seorang laki-laki dan perempuan menjadi sah secara agama
(Dariyo, dalam Marlina, 2013). Menikah merupakan titik awal dari kehidupan berkeluarga dan tujuan yang ditetapkan dalam pernikahan akan berdampak pada kehidupan pernikahannya secara keseluruhan (Manap, Kassim, Hoesni, Nen, Idris, \& Ghazali

2013). 
Tujuan dari pernikahan adalah untuk membentuk keluarga yang sejahtera dan bahagia selamanya (Agustian, 2013). Adapun menurut Undang-undang Perkawinan no. 1 tahun 1974 pasal 1, bahwasanya perkawinan adalah ikatan lahir batin antara seorang pria dan seorang wanita sebagai suami istri dengan tujuan membentuk keluarga atau rumah tangga yang bahagia dan kekal berdasarkan Ketuhanan yang Maha Esa.

Pernikahan harmoni merupakan dambaan setiap pasangan. Kehidupan pernikahan merupakan pintu awal pasangan untuk beradaptasi dan saling memahami. Perbedaan latar belakang, usia, tingkat pendidikan menjadi tidak berarti jika penerimaan pada masuknya siklus kehidupan berkeluarga di terima dan di pahami dengan baik. Kondisi inilah yang menjadi dasar menarik untuk membangun keluarga berkualitas.

Undang-undang Nomor 52 tahun 2009 tentang Perkembangan Kependudukan dan Pem-bangunan Keluarga, Pasal 1 menyebutkan bahwa perkembangan kependudukan dan pembangunan keluarga adalah upaya terencana untuk mewujudkan penduduk tumbuh seimbang dan mengembangkan kualitas penduduk pada seluruh dimensi penduduk. Pasal tersebut tentu mendorong untuk memperhatikan kualitas pernikahan dan harmoni yang terbangun di dalamnya.

Kualitas pernikahan seharusnya diraih pada setiap pasangan nikah, namun demikian hal tersebut sangat bertentangan dengan laporan yang menyebutkan bahwa tingkat perceraian lima tahun terakhir mengalami peningkatan, dengan rincian dari dua juta pasangan menikah, sebanyak 15 hingga 20 persen bercerai. Sementara, jumlah kasus perceraian yang diputus Pengadilan Tinggi Agama seluruh Indonesia pada 2014 mencapai 382.231, naik sekitar kasus 131.023 dibanding tahun 2010 sebanyak 251.208. Fakta ini tentu menjadi persoalan yang harus segera di pecahkan. Artinya Dirjen Bimas Islam memiliki tugas penting khususnya mencari solusi untuk mengurangi laju perceraian yang tentu menjadi persoalan perkembangan anak, serta kualitas manusia pada umumnya.

Menurut data awal yang diperoleh peneliti dalam wawancara dengan bagian kepenghuluan, selama ini konflik dalam pernikahan di mediasi melalui konseling, sebagai langkah sebelum memutuskan perceraian. Akan tetapi, konseling tersebut tidak selalu dapat mendamaikan pasangan suami-istri. Tugas pokok dan teknis pelaksanaan tugas penghulu berdasarkan Pasal 6 angka 3 Peraturan Menteri Pendayagunaan Aparatur Negara Nomer: PER/62/M.PAN/6/2005, penghulu memiliki tugas dalam lima bidang, yaitu: 1) pengkajian masalah hukum munakahat, 2) pengembangan metode penasihatan, konseling dan pelaksanaan nikah/rujuk, 3) pengembangan perangkat dan standar pelayanan, 4) penyusunan kompilasi fatwa hukum munakahat, dan 5) koordinasi kegiatan lintas sektoral di bidang nikah dan rujuk (Mudzakir, 2005). Tugas pada nomor 3 tidak sebatas program Desa Binaan Keluarga Sakinah (DBKS) yang selama ini telah tersistem dengan baik, namun harus ada model pelayanan baru untuk penguatan pernikahan sebagai upaya memberikan pemahaman dan ketrampilan pasangan suami-istri dalam menghadapi persoalanpersoalan pernikahan.

Kehidupan pernikahan menurut Santrock (1995) adalah masuknya individu ke dalam lima tahapan siklus kehidupan keluarga, yaitu dengan persiapan meninggalkan rumah sebagai individu yang mandiri dan bertanggung jawab emosional dan finansial. Sayangnya tidak semua pasangan melakukan persiapan pertanggungjawaban pribadi saat menikah dan berkeluarga secara baik. Bahkan dalam penelitian Doss, Rhoades, Stenly, \& Markman (2009) disebutkan bahwa pasangan dengan usia pernikahan lima tahun akan mengalami berbagai masalah yang timbul. Persoalan tersebut memerlukan adanya program pengayaan pernikahan atau marriage enrichment sebagai upaya untuk mempromosikan komitmen yang seimbang dan berkembang dalam hubungan pernikahan, untuk 
mengembangkan dan bersepakat dalam tipe komunikasi, mendengarkan dan belajar bagaimana menggunakan konflik untuk pertumbuhan bukan untuk menghindari.

Peneliti melihat urgensi penelitian ini untuk dilakukan dalam rangka membuat model baru pelayanan yang berbasis self help di mana ketrampilan penguatan pernikahan di berikan bukan saat masalah atau konflik terjadi namun pada setiap pasangan yang telah menikah di lima tahun awal dan lima tahun kedua agar menjadi panduan diri dalam mengatasi masalah yang dihadapi.

Penelitian ini bertujuan untuk mengeksplorasi masalah yang terjadi pada pernikahan usia di bawah sepuluh tahun, yaitu lima tahun awal dan lima tahun kedua dan mengidentifikasi strategi pasangan suami-istri dalam menyelesaikan permasalahan tersebut. Penelitian ini diharapkan dapat menjadi studi awal yang menjadi dasar pengembangan model baru pelayanan psikologis Dirjen Bimas Islam dalam mendampingi pasangan suami-istri dalam kehidupan rumah tangga, khususnya oleh Bagian Kepenghuluan. Program keluarga sakinah dan pemantapan di bidang keagamaan dalam keluarga telah sukses menjadi program yang tersusun dan terencana. Untuk itu harus ada program penguatan pernikahan bagi pasangan nikah agar keutuhan, keharmonisan dan kebahagiaan dalam keluarga dapat terwujud. Peran bagian kepenghuluan sebagai fasilitator psikologis yang dapat mengajarkan pada pasangan suami-istri untuk melakukan strategi self help pada masalah-masalah yang di hadapi.

Perubahan kondisi pernikahan banyak terjadi setelah memasuki usia pernikahan lima tahun ke atas. Hal ini menunjukkan bahwa dalam kehidupan pernikahan setalah lima tahun pasangan suami-istri mengalami guncangan dan beberapa permasalahan. Penelitian Doss, dkk. (2009) mengungkapkan bahwa 36\% dari 213 pasangan mengalami masa sulit dan mencari penyelesaian dari buku-buku mengenai hubungan pasangan suami istri, 41 pasangan mengikuti workshop dan 49 pasangan membaca buku-buku tema meningkatkan hubungan.

Konsep penguatan pernikahan sangat di perlukan dalam prevensi hubungan pasangan suami istri. Konsep ini muncul pertama kali pada awal abad 20 yang mempromosikan komitmen timbal balik dalam perkembangan khususnya hubungan pernikahan, pengembangan dan kesepakatan dalam tipe komunikasi, mendengarkan yang dapat menguatkan hubungan pasutri, terkait dengan berbagi perasaan, pengembangan hubungan yang lebih erat, dan ketrampilan interaksi yang positif. Penelitian dan pelatihan mengenai penguatan pernikahan ini sangat penting dalam memahami permasalahan dan persoalan yang terjadi dalam perjalanan pernikahan. Saran dari penelitian pada penguatan pernikahan lebih difokuskan pada persoalan yang terjadi dalam pernikahan, bagaimana membina hubungan pernikahan yang sehat, sehingga hal ini sangat berdampak pada hubungan pasangan dan perkembangan anak yang optimal dalam keluarga.

Dari hasil reviu literatur, ditemukan ada 13 program penguatan pernikahan. Empat program diantaranya efektif, tiga mendekati efektif dan enam belum teruji keefektifannya. Telaah penelitian dari tahun 1970 sampai 2003 menemukan program PREP (The Prevention and Relationship Enhancement Program) sebagai program penguatan pernikahan. Program tersebut menggunakan pendekatan yang berorintasi pada ketrampilan berdasarkan faktor-faktor penyebab kegagalan pernikahan. Terdapat empat tujuan pelatihan, yaitu mengajarkan pasangan komunikasi yang lebih baik, strategi menejemen konflik dan memberi contoh kepada pasangan masing-masing dalam mengklarifikasi dan evaluasi yang diharapkan, mempromosikan pemahaman dan refleksi komitmen yang di pilih, dan menguatkan ikatan dalam hubungan. Pelatihan ini diagendakan selama 12 jam atau enam sesi dengan dua jam tiap sesinya dan tiap pasangan di gabungkan dalam kelompok. Hasil dari PREP menunjukkan peningkatan efektifitas dalam komunikasi pada pasangan dibanding pada kelompok 
yang tidak memperoleh pelatihan, meningkatkan kepercayaan diri dalam hubungan pasangan suami istri, peningkatan komunikasi dalam problem solving, pengurangan perceraian, menambah kepuasan pernikahan dan mengurangi permasalahan.

Jakubowski, Milnes, Brunner, \& Mille, (2004) menjelaskan mengenai relationship enhancement yaitu pelatihan untuk pasangan dan juga perkembangannya bagi pasangan sebelum pernikahan, orangtua, anak, ibu dan saudara. Program ini fokus mengajarkan ketrampilan self-disclosure terutama pada perasaan, perilaku dan eliminasi kalimat atau pernyataan yang bersifat menyalahkan serta mengajarkan ketrampilan mendengar (pemahaman dan penerimaan selfdisclosure). Enam ketrampilan yang di ajarkan terdiri dari empati, ekspresi, diskusi, negosiasi, resolusi konflik, memfasilistasi pasangan pada perubahan diri, perubahan orang lain, generalisasi dan mempertahankan. Program penguatan dilaksankan pada dua jam tiap minggu selama 10-15 minggu. Program ini menunjukkan adanya peningkatan komunikasi, kepuasan, adaptasi hubungan, empati, kehangatan, natural dan kepercayaan dalam penikahan.

Program lainnya yaitu The Couple Communication Program (CCP) bertujuan untuk meningkatkan kesadaran diri dan pasangan, hubungan, peran konflik, dan komunikasi yang terbuka pada pasangan. Program ini dilakukan selama dua jam setiap minggu selama empat minggu, berdampak pada kepuasan, komunikasi dan kualitas pernikahan.

Program selanjutnya yang dinilai efektif adalah Strategic Hope-focused Enrichment yang ditujukan untuk mempromosikan cinta, keyakinan pada pasangan dan bekerja sama untuk memotivasi pasangan dalam pernikahan. Program ini terdiri dari lima sesi. Tiap sesi berduasi satu jam. Peserta program ini diharapkan dapat meningkatkan komunikasi, intimasi, dan pelatih memberikan umpan balik pada keterampilan komunikasi, keterampilan resolusi konflik, training perilaku positif, intimasi dan pengembangan latihan.

Hasil yang paling mendekati efektif adalah Couple Care: Couple Commitment and Relationship Enhancement, hampir sama dengan PREP ACME atau Association for Couple in Marriage, program ini di gunakan untuk meningkatkan hubungan sebuah pernikahan yang menggunakan format proses belajar dari pasangan. Terdapat 10 prinsip yang digunakan dalam program ini, antara lain pernikahan yang sehat, keterampilan hubungan, dan penguatan pernikahan. Program ini terbukti efektif memberikan dampak positif pada pasangan berupa, peningkatan resolusi konflik, kualitas hubungan, komunikasi, ekspresi komitmen pada pernikahan dan intimasi.

CCET atau Couple Coping Enhancement Training adalah program prevensi pada masalah pernikahan yang mengkombinasikan Terapi Kognitif dan Perilaku dengan teori stres, coping, dan pertukaran sosial. Tujuan program atau pelatihan ini membantu pasangan mendapatkan ketrampilan baru yang dapat meningkatkan komunikasi dalam pernikahan, problem solving, manajemen stres, coping, dan pasangan memiliki kepekaan pada isu kesetaraan/keadilan dalam relasi. Waktu yang di butuhkan 18 jam dalam enam minggu.

Ada enam program yang belum terbukti secara empiris yaitu Structured Enrichment (SE), Marriage Encounter (ME), The Practical Aplication of Intimate Relationship Skills (PAIRS), Imago Relationship Therapy (IRT), Traits of a Happy Couple (THC), Saving Your Marriage It Starts (SYMBIS). Model-model di atas memberikan gambaran bagaimana penguatan pernikahan dapat memberikan self-help bagi pasangan suamiistri khususnya PREP yang dapat menjadi model self-help yang dapat dikembangkan di bagian kepenghuluan sebagai bagian pelayanan baru bagi pasutri dengan usia pernikahan 5-10 tahun. Terkait dengan telaah di atas penelitian ini bertujuan untuk memahami permasalahan yang dihadapi 
pernikahan khsususnya pasangan suami-istri yang berasalah dari Indonesia, strategi pemecahan masalah yang dilakukan dan faktor-faktor yang mempengaruhi. Hal ini dapat menjadi studi pendahuluan untuk pembuatan model self-help yang dapat dilakukan pasutri dan dapat di sampaikan bagian kepenghuluan pasangan sebelum menikah dan program konseling setelah pernikahan .

Tugas perkembangan pada masa dewasa awal adalah mulai bekerja, memilih pasangan, belajar hidup dengan orang lain, mulai membina keluarga dan mengasuh anak (Santrock, 1995). Saat itulah individu dewasa awal mulai masuk dalam tahapan siklus kehidupan keluarga, sehingga selain tanggung jawab emosional dan finansial individu perlu memiliki ketampilan adaptasi dalam pernikahan.

Meski di sebagian wilayah di katakan bahwa menikah merupakan konstruksi sosial yang di bangun, menjadi suatu pilihan hidup, menikah atau untuk tidak menikah. Undangundang tentang perkawinan No 1 tahun 1974, pasal 1 menyatakan bahwa perkawinan ialah ikatan lahir batin antara seorang pria dengan seorang wanita sebagai suami istri dengan tujuan membentuk rumah tangga yang bahagia dan kekal berdasarkan Ketuhanan Yang Maha Esa. Hakikat pernikahan tidak hanya sebatas gaya hidup pilihan, namun sarat dengan makna ibadah. Menurut Seyal (2006) pernikahan adalah hubungan laki-laki perempuan dalam ikatan suci dan syarat dengan nilai-nilai spiritual dan moral. Terbentuknya pernikahan tidak menjadi hal utama yang diulas, namun bagaimana pernikahan dapat membawa kehidupan yang bahagia, tenang dan tentram perlu usaha dan pendampingan untuk mencapainya.

Mayoritas masyarakat sepakat bahwa pernikahan dianggap sebagai cara terbaik menjamin keteraturan dalam membesarkan anak. Pada pernikahan idealnya pasangan mendapatkan intimasi, komitmen, persahabatan, kasih sayang, pemuasan seksual, pendampingan dan peluang bagi pertumbuhan emosional, serta sumber indentitas dan kepercayaan diri yang baru (Myers dalam Papalia, Wendkos, \& Feldman 2008)

Psikologi memberikan fokus dan penekanan pernikahan dan membina keluarga dalam tugas perkembangan. Neugarten (dalam Papalia dkk, 2008) menyebutkan bahwa model timing of event menentukan peristiwa kehidupan normatif yaitu peristiwa-peristiwa yang terjadi pada sebagian besar orang dewasa pada waktu tertentu dalam kehidupan di antaranya adalah pernikahan dan menjadi orangtua. Merujuk pada model ini seseorang dapat melakukannya sesuai dengan waktu yang di tentukan sendiri atau waktu yang di tentukan oleh norma sosial di mana seseorag tinggal.

Social clock atau waktu sosial di Indonesia sangat beragam mengenai kapan waktu yang tepat untuk menikah. Secara hukum dan kesehatan di sebutkan waktu yang baik untuk menikah pada laki-laki adalah 25 tahun dan perempuan 20 tahun. Harapan sosial menghendaki seseorang mandiri secara finansial, dan melanjutkan pada pernikahan. Hal itu juga dapat di lakukan secara bersamaan mencoba untuk mandiri secara finansial dan menikah.

Menurut Carter, \& McGoldrick (dalam Santrock, 1995) ada enam tahapan siklus kehidupan keluarga, yaitu: 1) meninggalkan rumah, 2) penggabungan keluarga melalui pernikahan (pasangan baru), 3) menjadi orangtua dan keluarga dengan anak, 4) keluarga dengan anak remaja, 5) keluarga pada kehidupan usia tengah baya, 6) keluarga pada kehidupan usia lanjut. Tahapan ini merupakan perubahan pada individu dan atau pasangan yang memerlukan proses untuk yang berkembang secara berkelanjutan. Saat individu masuk tahapan masa dewasa ada transisi yang yang harus terbangun yaitu komitmen pada sistem baru dan adaptasi pernikahan yang mencakup berbagi tanggung jawab, komunikasi yang sehat pada pasangan sepanjang waktu, kehidupan seks, dan perubahan hubungan tiap tahap. 
Penelitian ini mengeksplorasi masalah yang

Adaptasi pernikahan terkait dengan perbedaan latar belakang, pendidikan, suku bahkan agama. Pada penelitian Valler, Ellison, \& Powers (2009) menemukan bahwa agama menjadi faktor penyebab keretakan rumah tangga, disebutkan bahwa jika salah satu pasangan sangat taat, lebih tekun dalam menghadiri ritual agama dan perayaan akan menjadi pemicu ketidak utuhan pernikahan. Namun lebih jauh hal tersebut juga memiliki dampak positif yaitu agama menjadi penguat kepuasan pernikahan, terhidar dari kekerasan dalam rumah tangga (KDRT) dan perselingkuhan. Sementara itu, fakta penyabab perceraian di Indonesia menurut Dirjen Bimas Islam Kementrian Agama yaitu KDRT, ekonomi, ketidakcocokan hingga masalah kesehatan pasangan. Hal tersebut mendorong perlu adanya upaya semua pihak untuk mengokohkan pernikahan, baik pasangan suami-istri dan juga peran Dirjen Bimas Islam dan Urais. Kuatnya ikatan lahir dan batin inilah yang mendorong individu untuk beradaptasi dengan kehidupan pernikahan. Melihat bahwa saat ini kehidupan pernikahan mengalami berbagai tantangan dan sekaligus di saat yang bersama pasangan suami dan istri dituntut memiliki ketrampilan atau cara yang dapat menyelesaikan permasalahan yang di hadapai.

Permasalahan perceraian dan keluarga tergantung kekuatan pada setiap keluarga. Program penguatan pernikahan ini tidak diberikan pada pasangan saat konflik atau menjelang perceraian, namun upaya yang di lakukan untuk mengantisipasi persoalan yang timbul dalam proses adaptasi dalam kehidupan pernikahan. Penelitian literatur studi mengenai program penguatan ini telah di buktikan secara empiris dan sangat efektif oleh Jakubowski dkk. (2004) salah satunya adalah PREP yang hasilnya menunjukkan bahwa peningkatan efektifitas dalam komunikasi pada pasangan di banding pada grup yang tidak di latihkan, meningkatkan kepercayaan diri dalam hubungan pasutri, peningkatan komunikasi dalam problem solving, pengurangan perceraian, menambah kepuasan pernikahan dan mengurangi permasalahan. dihadapi pernikahan berusia 5-10 tahun dimaksudkan untuk memahami permasalahan yang muncul di lima tahun awal pernikahan dan lima tahun kedua. Hasil penelitian ini juga diharapkan menjadi acuan untuk menyusun panduan penguatan pernikahan yang harus masuk dalam konseling pra nikah dan sebagai tambahan model konseling pasca pernikahan.

\section{METODE}

Metode yang digunakan dalam penelitian ini adalah metode kualitatif berupa studi kasus. Metode studi kasus ini melibatkan beberapa kasus yang mewakili penelitian studi awal. Subjek dalam penelitian ini dipilih dengan karakteristik pasangan suami istri yang telah menikah 5-10 tahun dan tinggal di Yogyakarta, beragama Islam. Dari semua kasus yang diangkat dipilih subjek dengan usia pernikahan 5, 6, 7, dan 10 tahun. Informan atau subjek dari penelitian ini berjumlah 4 orang. Pertanyaan yang hendak dijawab dalam ini adalah: Apa masalah yang muncul di lima tahun awal pernikahan dan lima tahun kedua pernikahan? Bagaimana strategi pasangan suami-istri menyelesaikan masalah yang terjadi ?

Studi kasus dalam penelitian akan melihat time sequence atau kasus yang unik dari waktu yang terlihat dalam pernikahan subjek ada 2 hal yang di perdalam yaitu : 1) menggali masalah-masalah yang muncul dalam pernikahan, 2) mengeklporasi upaya dalam mengatasi masalah yang biasa mereka hadapi dalam kehidupan pernikahan pasangan suami-istri yang telah menikah pada lima tahun awal dan lima tahun kedua dalam pernikahan.

Menegakkan keabsahan dan validitas data yang di peroleh dalam penelitian ini dengan cara triangulasi sumber yaitu membandingkan hasil wawancara, hasil observasi serta dokumen yang di perlukan dalam penelitian ini. Selian itu ketekunan pengamatan dengan cara menemukan kedalaman hasil pengambilan data, melalui proses analisis jawaban subjek yang 
konsisten dalam beberapa proses pengambilan data.

\section{HASIL DAN PEMBAHASAN}

Pernikahan di Indonesia masih menjadi hal yang sangat penting untuk dilalui pada tahap dewasa awal. Hal yang menarik dari pernikahan di Indonesia, pernikahan tidak hanya sebatas pilihan dari gaya hidup, namun masih memiliki muatan ibadah yang ada di dalam pernikahan.

\section{Kasus 1}

Saat ini pernikahan Esti, telah berusia lima tahun. Esti menikah pada usia 26 tahun seteleh menyelesaikan studi S2, dan suaminya 32 tahun setelah S1. Keduanya telah memiliki dua anak. Keduanya menikah setelah berpacaran selama studi S1. Meski keduanya memiliki latar belakang agama dan status sosial yang tidak jauh berbeda. Pada awalnya pernikahan keduanya di tentang karena jarak asal yang cukup jauh dari asal Esti. Namun setelah Esti dapat meyakinkan orangtua akhirnya kedunya mendapatkan restu. Masalah yang muncul dari Esti dalam pernikahan adalah masalah ekonomi, Meski suaminya telah bekerja sebelum menikah. Permasalahan yang muncul di awal pernikahan adalah masalah ekonomi, adaptasi dengan adik ipar dan komunikasi yang belum terbuka dengan suami. Masalah ekonomi dengan berjalannnya waktu dapat diatasi dengan keuletan dan ketekunan dan juga satu tahun yang lalu Esti ikut bekerja. Tahun kedua pernikahan adik iparnya ikut tinggal bersama selama dua tahun, saat itu Esti merasa tidak belum mampu untuk membicarakan secara terbuka perbedaan kebiasaan. Strategi yang di gunakan dalam menyelesaikan masalah dengan membuka komuniksi agar lebih nyaman dan dipahami, dan tidak melibatkan keluarga dalam menyelesaikan masalah.

Kasus 2

Yulia telah menikah selama enam tahun dengan suaminya, telah di karunia seorang anak. Saat menikah Usia Yulia 33 tahun dan suaminya lebih muda yaitu 28 tahun. Di awal pernikahan Yulia tidak cocok dengan mertuanya, akhirnya Yulia dan suaminya memutuskan untuk tinggal di rumah masingmasing. Hal itu di lakukan kurang lebih 5-6 tahun. Keduanya bertemu tiap tiga hari sekali. Yang menjadi maslah di awal pernikahan adalah masalah ekonomi, karena beberapa saat setelah menikah suaminya mengalami pemutusan hubungan kerja di mana dia bekerja. Setelah itu suaminya bekerja sebagai petani dan kurir katering sedangkan Yulia bekerja sebagai buruh jahit di pabrik. Strategi yang digunakan dalam menyelesaikan adalah mengatur keuangan, komunikasi yang lebih baik, dan saling menguatkan.

\section{Kasus 3}

Eka telah menikah selama tujuh tahun. Eka menikah saat berusia 19 tahun dan suaminya 27 tahun telah memiliki seorang anak. Pada awal pernikahan ekonomi tidak menjadi persoalan, hanya masalah kebiasaan Eka yang sulit untuk bangun pagi. Ketidakcocokan dengan keluarga suami, mertua, dan suaminya sering tidak menghargai. Setelah menikah masalah yang muncul adalah perbedaan pengasuhan anak, suaminya mendidik deangan lembut, sedangkan dirinya mendidik dengan cara yang keras. Eka juga memiliki kebiasaan menuntut suaminya. Suaminya juga tidak perhatian dengan Eka. Strategi yang digunakan adalah saat terjadi konflik Eka pulang ke rumah orangtua, namun lambat laun itu tidak di lakukan lagi, membuka komuniksi dengan suami.

\section{Kasus 4}

Ami telah menikah selama 10 tahun, menikah pada usia 37 tahun dan suaminya 33 tahun, telah memiliki seorang anak. Di awal pernikahan yang menjadi kendala adalah masalah ekonomi. Namun dengan berjalananya waktu hal itu dapat diatasi dengan baik. Suaminya tidak rapi, tidak perhatian, tidak romantis dan sangat perhitungan. Masalah saat ini yang sering muncul adalah perbedaan pengasuhan anak, perbedaan pendapat, kebiasaan suami yang pergi tanpa pamit serta kebiasaan baik istri salaman dan mengantarkan ke depan rumah sudah mulai pudar atau hilang. Strategi yang dilakukan untuk menyelesaikan masalah adalah lebih sabar menghadapi suami, 
131

mengalah dan kadang memilih untuk marahmarah.

Usia pernikahan di Yogyakarta khususnya masih relatif mengikuti kebiasan norma setempat di bawah usia 25 tahun, pada kasus tertentu terkait faktor pekerjaan dan pendidikan mereka dapat menikah di atas 30 tahun. Usia perempuan yang lebih tua daripada suami saat ini tidak menjadi permasalahan yang penting. Hal itu sama dengan yang di alami oleh Yulia dan Ami yang keduanya menikah pada usia yang lebih tua. Saat terjadi konflik, pada istri yang usia lebih tua seperti Ami memilih untuk sabar, dan mengalah.

Masalah yang terjadi di lima tahun awal pernikahan hampir dialami semua subjek adalah masalah pendapatan atau ekonomi. Namun dengan berjalannya waktu masalah itu dapat diatasi dengan baik.

Menurut Carter \& McGoldrick (Santrock, 1995) ada enam tahapan siklus kehidupan keluarga, yaitu: 1) meninggalkan rumah, 2) penggabungan keluarga melalui pernikahan (pasangan baru), 3) menjadi orangtua dan keluarga dengan anak, 4) keluarga dengan anak remaja, 5) keluarga pada kehidupan usia tengah baya, 6) keluarga pada kehidupan usia lanjut. Pada kasus 1 hingga 4 menunjukkan saat subjek meninggalkan rumah untuk menikah ada tata cara atau adaptasi yang harus dilakukan dengan keluarga baru.

Subjek Esti, Yulia dan Eka semua mengalami hal yang berkaitan dengan adaptasi dengan keluarga suami baik itu mertua, adik ipar atau mungkin keluarga yang lain. Tentu hal ini harus dapat di atasi dengan baik, jika tidak akan menjadi penyebab kesulitan adaptasi pada pasangan, yang tentunya berdampak pada hubungan jangka panjang. Berbeda dengan Eka selain adaptasi dengan keluarga, juga mengalami kesulitan berdaptasi dengan kebiasaan lama sebelum menikah, yaitu kesulitan untuk bangun lebih awal atau pagi.

Masalah ekonomi dan adaptasi baik dengan pasangan dan keluarga menjadi hal yang perlu diperhatikan di lima tahun awal pernikahan. Strategi yang harus dipersiapkan dalam menghadapi masalah di atas adalah dengan membangun kesiapan dalam bekerja khususnya pada laki-laki dan perempuan (saat ada kesempatan dan kesepakan dengan suami).

Adapun masalah yang terjadi di lima tahun kedua yaitu 6-10 tahun pada informan menunjukkan bahwa suami di-PHK sehingga istri menjadi pencari nafkah tunggal, perbedaan pendapat dalam pengasuhan anak, dan kebiasaan positif istri atau suami yang mulai hilang dengan berjalannya waktu. Kebiasaan istri mencium tangan saat suami pergi, dan suami berpamitan saat akan meninggalkan rumah. Strategi yang harus dilakukan untuk menguatkan pernikahan adalah dengan membuka komunikasi yang lebih positif, menyatukan kembali dengan pasangan dengan mengembalikan kebiasaan positif di awal pernikahan. Hal tersebut akan mudah apabila kedua pasangan dapat berusaha dan menjalankan bersama, juga adanya keterbukaan dengan apa yang disukai dan tidak disukai.

Hasil tambahan yang menarik dari penelitian ini adalah adanya masukan kepada bagian kepenghuluan untuk menambah jam sesi konseling sebelum pernikahan, memahami latar belakang pengantin, karakter dan kebiasaan serta bagaimana mengatasi masalah yang terjadi setelah pernikahan. Hal ini tentunya dapat bekerjasama dengan pihak lain untuk memberikan konseling. Selain itu pasca pernikahan diperlukan adanya penguatan pernikahan dengan cara konseling kelompok untuk menyatukan kembali pasangan dan mengatasi masalah seperti seksual, pengasuhan anak dan mengembalikan kebiasaan positif pasangan.

Saran untuk peneliti selanjutnya adalah melihat rentangan pernikahan dari awal hingga usia lanjut dan bagaimana pasangan beradaptasi dengan bertambahnya usia, pengasuhan anak menuju remaja dan dewasa, dan bagaimana budaya dan agama dapat memberikan kontribusi dalam mengatasi masalah yang ada. Selain itu penelitian ini dapat dilanjutkan dengan 
metode eksperimen dengan menyusun pelatihan penguatan di lima tahun awal dan lima tahun kedua pernikahan. Kelemahan dari penelitian ini waktu pengambilan data yang sangat terbatas disebabkan pekerjaan dan kesibukan subjek.

\section{SIMPULAN}

Penelitian ini mendapatkan masalah-masalah yang muncul dalam pernikahan di bawah sepuluh tahun, yaitu pada lima tahun awal dan lima tahun kedua. Hasil penelitian ini akan direkomendasikan kepada Bagian kepenghuluan sebagai pedoman pendampingan konseling pra nikah dan pengauatan pernikahan setelah pernikahan. Pertama, pasangan dapat membangun kesiapan ekonomi dalam menjalankan kehidupan pernikahan dan menyatukan diri bersama pasangan dan atau keluarga sehingga terbangun adaptasi yang baik. Strategi yang harus dilakukan oleh pasangan adalah suami bekerja dengan tekun dan istri dapat membantu dalam menjalankan peran masing-masing, saat suami putus kerja atau mengalami kesulitan dalam pekerjaan, istri dapat membantu mencari nafkah tambahan sehingga kebutuhan finansial keluarga dapat di atasi dengan baik. Kedua, membuka kembali komunikasi yang lebih positif dan mengembalikan kebiasaan positif yang dapat menguatkan intimasi dan komitmen pernikahan. Strategi yang di gunakan adalah membuka komunikasi yang lebih positif dan menghangatkan pernikahan dengan kembali melakukan kebiasaan positif di awal pernikahan. Hal itu dapat dilakukan agar pernikahan menjadi lebih kuat, hangat dan bahagia.

\section{DAFTAR PUSTAKA}

Agustian, H. (2013). Gambaran kehidupan pasangan yang menikah di usia muda di Kabupaten Dharmasraya. Spektrum PLS, Vol. 1(1), 205-217.

Badaruddin., Sholihah, M., Suud, A., Mahlani, M., Aminudin., Rifa'i, S. (2012). Modul Kursus Pra Nikah. Yogyakarta: Seksi Urais Kemenag Kota Yogyakarta.
Doss, B. D., Rhoades, G. K., Stenly, S. M., \& Markman, H. J. (2009). Marital therapy, retreats, and books: The who, what, when, and why of relationship help-seeking. Journal of Marital and Family Therapy, 35(1), 18-29.

Ghozali, N.A., Nuroni, S., Kusnanto., Suparto., Badarudin., \& Musthofa, J. (2012). Pola pernikahan keluarga sakinah desa dan desa binaan keluarga sakinah (DBKS). Yogyakarta: Bidang Urais Kanwil Kemenag Agama DIY.

Jakubowski, S.F., Milnes, E.P., Brunner, H., \& Miller, R.B. (2004). A review of empirically supported marital enrichment programs. Family Relations ProQuest Sociology, 52 (5).

Manap, J., Kassim, A. C., Hoesni, S., Nen, S., Idris, F., \& Ghazali, F. (2013). The purpose of marriage among single malaysian youth. Procedia: Social and Behavioral Sciences, Vol. 82 , 112-116. http://dx.doi.org/10.1016/j.sbspro.201 $\underline{3.06 .233}$

Marlina, N. (2013). Hubungan antara tingkat pendidikan orangtua dan kematangan emosi dengan kecenderungan menikah dini. Empathy. 2(1).

Mudzakir. (2005). Pedoman penghulu. Jakarta: Dirjen Bimbingan Masyarakat Islam dan Penyelenggaraan Haji Kemenag RI.

Papalia, D. E., Wendkos, S., \& Feldman, R.D. (2008). Human development $9^{\text {th }}$ Edition. (Terjemahan: Ak. Anwar). Jakarta: Kencana.

Santrock, J. W. (1995). Life-span development. (Terjemahan : Chusairi, A. \& Damanik). Jakarta : Penerbit Erlangga 
Seyal, F. (2006). Together forever : Semailah cinta raih bahagia. (Terjemahan Mabni Darsi). Jakarta: Sanabil Pustaka
Valler, M.L., Ellison, C.G., \& Powers, D.A. (2009). Religious influences on the risk of marital dissolution. Journal of Marriage and Family ProQuest Sociology, 71(4). 